Saint Louis University School of Law

Scholarship Commons

All Faculty Scholarship

2011

\title{
Employees and the Boundaries of the Corporation
}

Matthew T. Bodie

Saint Louis University School of Law

Follow this and additional works at: https://scholarship.law.slu.edu/faculty

Part of the Business Organizations Law Commons, and the Labor and Employment Law $\underline{\text { Commons }}$

\section{Recommended Citation}

Bodie, Matthew T., Employees and the Boundaries of the Corporation (February 3, 2011). RESEARCH HANDBOOK ON THE ECONOMICS OF CORPORATE LAW, Edward Elgar, 2011; Saint Louis University Legal Studies Research Paper No. 2011-03. Available at SSRN: https://ssrn.com/abstract $=1754242$

This Article is brought to you for free and open access by Scholarship Commons. It has been accepted for inclusion in All Faculty Scholarship by an authorized administrator of Scholarship Commons. For more information, please contact erika.cohn@slu.edu, ingah.daviscrawford@slu.edu. 


\title{
Employees and the Boundaries of the Corporation
}

\author{
Matthew T. Bodie
}

\section{Introduction}

United States corporate law has little to say about employees. ${ }^{1}$ Employees are simply one category of the many parties who form contracts with the corporation. Although individual states have their own separate sets of corporate law, states uniformly delineate the roles of directors, officers, and shareholders in governing the entity. The relationships between these three groups constitute the purpose and function of corporate law (Clark 1986; Smith \& Williams 2008). The "employee" category is not a meaningful one when it comes to creating, sustaining, or dissolving the corporation (Greenfield 1998).

When it comes to the firm, however, as opposed to the corporation, employees take on a much more central role. In The Nature of the Firm, Ronald Coase singled out the relationship between the firm and its employees as the firm's defining feature (Coase 1937). This relationship has continued to be a focal point in the development of the theory of the firm particularly in differentiating between firms and market transactions (Greenfield 1998). In subject areas such as tort law, intellectual property law, and tax law, the employer-employee relationship provides the necessary contours in separating the firm from the market. And when it comes to other business organizations, especially partnerships, the providers of labor can have a critical role in the ownership and governance of the firm. ${ }^{2}$ Corporate law stands out in its exclusion of employees in defining and establishing the legal shape of the firm. ${ }^{3}$

This result is somewhat ironic, since corporate law is the area of law most influenced by the theories of the firm. Since the 1970s, scholars have focused on the interrelationship between the theory of the firm and the construction of corporate law. The "nexus of contract" theory of the corporation comes from Jensen \& Meckling's work on the firm (1976), and it remains foundational in the field (Easterbrook \& Fischel 1991; Bainbridge 2002). This theory, in brief, seeks to disaggregate our notion of the corporation as an entity and break it down into its component parts. These parts are the contractual relationships between the various sets of people involved with the firm: executives, directors, shareholders, creditors, suppliers, customers, and employees. The “corporation” itself doesn't really exist; it is merely the "nexus” (or connection) amongst these various corresponding relationships (Easterbrook \& Fischel 1989). Thus, the further irony: research into the theory of the firm has been used to establish that the corporation really is not a firm at all, but rather a series of contracts.

\footnotetext{
${ }^{1}$ This contribution concerns corporate law and scholarship in the United States. Other countries have had a greater role for employees in governance, with Germany's system of codetermination the most prominent example (Hansmann 1996; Pistor 1999; Roe 1999).

${ }^{2}$ For example, a partnership can be formed, and a partner can join a partnership, solely through labor contributions. Moreover, a partnership may be formed without an explicit agreement or even contrary to specific agreement, based on joint labor between two parties looking to share the fruits of their labor. Holmes v. Lerner, 74 Cal. App. 4th 442 (1999); Fenwick v. Unemployment Compensation Commission, 44 A.2d 172 (N.J. Err. \& App. 1945).

${ }^{3}$ Other forms of business organizations, especially workers cooperatives, allow for significant employee participation in governance (Hansmann 1996; Gulati, Isaac \& Klein 2002). This essay contribution, however, discusses the role of employees in corporations and corporate law.
} 
There is, however, a countervailing view. This essay seeks to recenter the notion of the corporation around the theory of the firm as a separate institution from the market. It will first provide a brief summary of the conventional view of the corporation and the role of employees within the corporation. It will then look to developments in the theory of the firm (both old and new) that provide for a more meaningful role for employees in defining the corporation. The essay then looks to other areas of law - tort law, intellectual property law, and tax law - for examples of how the employee-centered theory of the firm has already played a role in shaping the law. The essay concludes with a review of recent works that point to radically different possibilities for the future of firms and the employees within them.

\section{The role of employees in state and federal corporate law}

Corporations are fictional persons that are created through state corporate law. In order to form a corporation, individuals must follow the procedures established by the individual states. These procedures generally require the incorporating individuals to file a corporate charter, also known as the articles or certificate of incorporation. ${ }^{4}$ This charter provides the firm's basic structure: the corporation's name, information regarding the incorporators, the total number of shares the corporation may issue, and the nature of the business to be conducted. ${ }^{5}$ Other provisions regarding the governance structure are permitted but are not necessary. ${ }^{6}$ Once the corporation is up and running, control transitions from the incorporators to the board of directors. The board manages the firm and may bind the corporation through contracts and transfers of property. ${ }^{7}$ Shareholders select the directors at the annual shareholders meeting. ${ }^{8}$ Directors are bound to act in the interests of the firm through common law fiduciary duties of care, good faith, and loyalty. This structure - shareholders select the directors, who in turn run the corporation - represents the crux of corporate law.

Corporate law does sketch out rights and responsibilities for officers, who are employees of the firm. Delaware law, for example, appears to require the corporation to choose officers, including one (generally the secretary) to record the proceedings of shareholders and directors meetings. ${ }^{9}$ However, the corporation has the power to determine the exact number and nature of the officer positions. Officers owe fiduciary duties to the corporation, and they may be indemnified under corporate law for their acts in the corporation's service. ${ }^{10}$ They are selected by the board and generally serve at the pleasure of the board, but they have no formal decisionmaking roles in annual meetings, board decisions, mergers and acquisitions, or dissolution.

\footnotetext{
${ }^{4}$ Del. Code tit. 8, § 101(a).

${ }^{5}$ Id. $\S 102$.

${ }^{6}$ Such structures may include a limitation on the liability of directors for breaches of the duty of care (id. $\S$ 102(b)(7)) or the provision for a staggered board of directors (Klausner 2006).

${ }^{7}$ Id. $\S 141$.

${ }^{8}$ Id. $§ 211$.

${ }^{9}$ Id. $§ 142$.

${ }^{10}$ Id. $\S 145$.
} 
Employees are generally hired by the officers and other employees on behalf of the corporation; their role within the corporate structure is purely contractual. The permeability of these categories means that employees can also play a role as shareholders, as directors, or both. These roles are often intermixed in closely-held corporations, ${ }^{11}$ but it is also common for the chief executive officer of a public corporation to hold a position on the board as well as a large number of shares. ${ }^{12}$ Employees can hold stock directly through a 401(k) plan, or indirectly through a money market account or even an employee stock ownership plan (ESOP). ${ }^{13}$ These overlapping roles do create a ripple in the securities laws, as, for example, employees may be offered the corporation's securities without the need for certain registration requirements. ${ }^{14}$ For the most part, however, employees are treated as regular investors. ${ }^{15}$

Of course, corporations can be structured in myriad ways. They can provide for employee board representatives by structuring classes of stock to provide for such representation. In perhaps the most famous example of employee board representation, the board for United Airlines had three employee representatives (out of twelve directors) when it underwent its 1994 restructuring (Blair 2001; Gordon 1999; Hansmann 2006). Given that employees owned fiftyfive percent of the company through an ESOP, three directors gave employees less than their proportional allocation. However, the structure was still controversial. The ESOP and concomitant board structure was eventually unwound when the company entered bankruptcy. United is the exception that proves the rule. Nothing requires an ESOP plan to put employee representatives on the board, and it is in fact a fairly unusual structure to find. ${ }^{16}$

Why do employees have no role in corporate law? The simple - and perhaps tautological - answer is that corporate law does not concern employees. Corporate law focuses on the structure of firm governance, which involves shareholders, directors, and officers. Employees can take on the roles of shareholders and directors, but the employment relationship is contractual and outside the scope of corporate law. Of course, this begs the follow-up question: how can the corporation be constructed without reference to employees? As explained in the following sections, employees are crucial to our understanding of the firm not only in the academic literatures, but in many other areas of the law.

\section{Employees and the theory of the firm}

\footnotetext{
${ }^{11}$ In fact, the doctrine of "minority oppression" in closely-held corporations often concerns the ability of the majority to deprive the minority of some of its rightful stake in the corporation, particularly employment (Moll 1999).

12 Some statutory schemes may exclude management or supervisors from the definition of employee. For example, the National Labor Relations Act excludes supervisors and managers. 29 U.S.C. § 152(11). However, the more common meaning covers anyone who works for the "employer" (i.e., the corporation).

${ }^{13}$ Gordon (1997) discusses the dynamics of employee equity ownership through pension funds. For further discussion of employee ownership interests, particularly stock options, see Bodie (2003).

1417 C.F.R. § 230.701.

${ }^{15}$ See SEC v. Ralston Purina Co., 346 U.S. 119 (1953) (refusing to exempt offerings to employees from securities registration requirements).

${ }^{16}$ As one example, during its existence as an ESOP-owned company, Avis did not have any employee representatives on its board (Hirsch 1995).
} 
Employees have been central to our conception of the firm from the start. The neoclassical theory of the firm is renowned for its emptiness; neoclassical economics simply saw the firm as a black box which took in inputs and produced outputs. However, this theory did differentiate between what was inside the firm and what was outside: employees and capital assets were inside, while customers and suppliers were outside (Rock \& Wachter 2001, p. 1631; Milgrom \& Roberts 1992). Although this conception of the firm was useful in early economic modeling and retains that purpose even today, it was ripe for a reinvestigation that endeavored to give it substance.

Coase offered a new theory in The Nature of the Firm (1937). In a passage that has been oft-quoted, Coase framed the issue in this manner:

Outside the firm, price movements direct production, which is coordinated through a series of exchange transactions on the market. Within a firm these market transactions are eliminated, and in place of the complicated market structure with exchange transactions is substituted the entrepreneur-coordinator, who directs production. It is clear that these are alternative methods of coordinating production. Yet, having regard to the fact that, if production is regulated by price movements, production could be carried on without any organization at all, well we might ask, why is there any organization? (Coase 1937, p. 388)

Coase's answer is that the price mechanism can be costly. For certain transactions, it is cheaper to simply direct the production to occur rather than contracting separately for it. In order to avoid the transaction costs of contracting, such transactions will occur within a firm rather than on an open market (Coase 1937, p. 390-92).

The firm-based transactions described by Coase involve the purchase of labor for a particular endeavor. In explaining these transactions, Coase states: "If a workman moves from department $\mathrm{Y}$ to department $\mathrm{X}$, he does not go because of a change in relative prices, but because he was ordered to do so" (p. 387). The relationship between the entrepreneur-coordinator and the employee is the primary distinction between the firm and the market. It is the reason for the firm's existence. Coase seems to be arguing that firms would be unnecessary, but for the need to remove the employment relationship from the vagaries of market transactions.

This conclusion is cemented when Coase considers "whether the concept of a firm which has been developed fits in with that existing in the real world" (p. 403). His answer? "We can best approach the question of what constitutes a firm in practice by considering the legal relationship normally called that of 'master and servant' or 'employer and employee.'” (p. 403) He then quotes at length from a treatise concerning the common law "control" test, which provides that " $\mathrm{t}] \mathrm{he}$ master must have the right to control the servant's work, either personally or by another servant or agent" (p. 404). He concludes: "We thus see that it is the fact of direction which is the essence of the legal concept of 'employer and employee,' just as it was in the economic concept which was developed above.” (p. 404) 
For Coase, the firm is defined by the employer-employee relationship (Orts 1998a). For Alchian \& Demsetz (1972), Coase's focus on control and authority is misleading. As they argue: "To speak of managing, directing, or assigning workers to various tasks is a deceptive way of noting that the employer continually is involved in renegotiation of contracts on terms that must be acceptable to both parties.” (p. 777) They frame their argument in these terms:

Telling an employee to type this letter rather than to file that document is like my telling a grocer to sell me this brand of tuna rather than that brand of bread. I have no contract to continue to purchase from the grocer and neither the employer nor the employee is bound by any contractual obligations to continue the relationship. Long-term contracts between employer and employee are not the essence of the organization we call a firm. (p. 777)

However, Alchian and Demsetz's critique of Coase's theory does not mean that employees are no longer central to the idea of the firm. They argue that the importance of the firm (as separate from the market) stems from the need to coordinate production in the midst of a variety of inputs. The need for a system of team production is what separates firms from markets. Alchian and Demsetz define team production as "production in which 1) several types of resources are used and 2) the product is not a sum of separable outputs of each cooperating resource" (p. 779). As a result, team production is used when the team method increases productivity, after factoring out the costs associated with monitoring and disciplining the team.

Alchian and Demsetz's model seems even more amenable to employee involvement in the firm than Coase's model. The primary concern of team production is making sure that the team members do not shirk their responsibilities to the team. The inability to measure individual contributions to productivity is what makes the firm possible, but it is also the firm's central governance problem. Alchian and Demsetz argue that a specialized, independent monitor may be the best way of insuring that the team members all contribute appropriately and are rewarded appropriately. That central monitor - the recipient of the residual profits - is the firm. Although both Coase and Alchian and Demsetz personify this monitor in the role of an entrepreneurcoordinator, such a collapse of powers into one human being is only possible in the smallest of firms. In order to meet the criteria set down by the model, ${ }^{17}$ the central component of team production is the firm itself: a "person" who contracts for all other team inputs.

It could be argued that Alchian and Demsetz conceived of a firm detached from employees, since the Alchian-Demsetz monitor must be outside the production process while being able to negotiate with all team members for their input and compensation. However, unless the "firm" is a sole proprietor, that monitor is merely a mechanism for providing coordination of inputs. And employees are the primary source of the inputs. It is true that Alchian and Demsetz seem to believe that the firm will be represented by a central figure who has claim to the entire residual, and thus an interest in coordinating the firm most efficiently. But they say nothing about who can appoint such a central figure. And in a lengthy discussion in

\footnotetext{
${ }^{17}$ Alchian and Demsetz (1972) set forth the following characteristics of the firm: (a) joint input production, (b) several input owners, (c) one party is common to all the contracts of the joint inputs, (d) who has the rights to renegotiate any input's contract independently of contracts with the other input owners, (e) who holds the residual claim, and (f) who has the right to sell his central contractual residual status.
} 
footnote 14, they express skepticism about the ability of shareholders to perform the monitoring function. Rather than characterize shareholders as owners, they argue that shareholders should be viewed merely as investors, like bondholders, albeit “more optimistic” ones. They ask:

In sum, is it the case that the stockholder-investor relationship is one emanating from the division of ownership among several people, or is it that the collection of investment funds from people of various anticipations is the underlying factor? If the latter, why should any of them be thought of as the owners in whom voting rights, whatever they may signify or however exercisable, should reside in order to enhance efficiency? Why voting rights in any of the outside, participating investors? (p. 789 n.14)

Thus, the Alchian-Demsetz team production model does not exclude employees from the definition of the firm. Although their model, with its focus on "inputs," broadens the scope of the firm to include investors as well as employees, the purpose of the Alchian-Demsetz firm remains the management of employees through the coordination of team production.

As theorists moved beyond these foundational works and into empirical research, the identification of transaction costs, monitoring costs, and team production have remained central concepts. The two primary theories of the firm in play today are the "transaction-costs" model and the "property rights" model. Using the transaction-costs model, Williamson and others have identified the types of contractual difficulties which are likely to lead to firm governance, rather than market solutions (Williamson 1985; Macher \& Richman 2008). In situations where contributions and compensation can be harder to define, the parties will be left with incomplete contracts that require a governance structure to prevent opportunism. This opportunism will be particularly problematic where one or both of the parties must invest significant resources in assets specific to the particular firm, project, or transaction. This asset specificity makes the parties susceptible to hold-ups from their contractual partners in the absence of a system of governance. Firms can be useful in providing the structures that deter opportunism (Williamson 1985,; 1996).

The focus on assets has carried over into the "property rights" theory of the firm. This theory, developed in a series of articles by Grossman, Hart, and Moore, argues that firms are necessary as a repository of property rights for assets used in joint production (Hart 1995, Grossman \& Hart 1986; Hart \& Moore 1988; Hart \& Moore 1990). By owning the property outright, the firm prevents the problem of the commons (in which no one holds property rights over valuable assets) as well as the problem of the anticommons (in which property rights are divvied up amongst too many disparate actors). The Grossman-Hart-Moore model dictates that the firm should be owned by those who contribute the most valuable and most asset-specific property to the joint enterprise. They are not only most necessary to the firm's success; they are also the most vulnerable to hold-up problems as the joint enterprise moves forward in time.

These theories have not enumerated the role of the employee in the firm, instead focusing on contracts and property rights. But the role of the employee in these models still remains critical. In the transaction costs model, employees' contributions must be recognized as assets of both the firm and the employee - often described as "human capital." Some types of human 
capital are transferable, such as education or general skills, but other types are specific to the firm and generally worthless outside it. To the extent an employee has invested in firm-specific skills, she is subject to opportunistic behavior, since she has little leverage to get the full value of those skills. In the transaction-cost model, employees may be precisely the vulnerable yet valuable contributors to the joint enterprise who have the most to fear from opportunistic behavior. $^{18}$

The property-rights model is also concerned with the relationship of employees to the firm. Although the property rights discussed in the model are generally nonhuman assets, the assets are "the glue that keeps the firm together" (Hart 1995, p. 57) and thus keep employees within the firm. Hart poses the following hypothetical: if firm 1 acquires firm 2, what is to stop workers at former firm 2 from quitting and forming a new entity?

For firm 1's acquisition of firm 2 to make any economic sense, there must be some source of firm 2 value over and above the workers' human capital, i.e. some 'glue' holding firm 2's workers in place. The source of value may consist of as little as a place to meet; the firm's name, reputation, or distribution network; the firm's files, containing important information about its operations or its customers; or a contract that prohibits firm 2's workers from working for competitors or from taking existing clients with them when they quit. . . . [W]ithout something holding the firm together, the firm is just a phantom. (p. 57)

Thus, the property-rights theory of the firm is designed in part to explain why the firm's employees remain with the firm. ${ }^{19}$

Recent scholarship has taken the role of human capital even further. The broad macroeconomic shift within the United States from manufacturing to service and creative industries has led one group of scholars to develop a knowledge-based theory of the firm (Gorga \& Halberstam 2007). According to the knowledge-based theory, "[t]he way the firm develops the knowledge it will use in its production process and the extent that firm can bind this knowledge to its structure will influence its organizational structure” (p. 1140). Rather than emphasize the ownership of physical assets, which can be fungible and non-specific, the knowledge-based theory focuses on the need to produce, distribute, and ultimately retain valuable knowledge-based assets within the firm. The primary generators of this knowledge are employees. Similarly, another approach known asthe capability-based theory of the firm focuses on firm-specific knowledge and learning that can be translated into joint production (McInerney 2004). This theory also emphasizes the role of employees as holders of the firm's capabilities.

Perhaps the model based on human capital that has been most well-received is Rajan and Zingales' "access" model of power within the firm (1998). ${ }^{20}$ The model defines a firm "both in

\footnotetext{
${ }^{18}$ Indeed, Blair offers the following critique: "The tendency of the transactions costs literature has been to recognize that firm-specific human capital raises similar questions, but then to sidestep the implications of these questions for corporate governance.” (Blair 2000, p. 66)

${ }^{19}$ But cf. Rajan \& Zingales (1998), p. 388 (“The property rights view does not consider employees part of the firm because, given that employees cannot be owned, there is no sense in which they are any different from agents who contract with the firm at arm's length.”).
} 
terms of unique assets (which may be physical or human) and in terms of the people who have access to these assets” (p. 390). Access to the unique assets is what defines the power of the individuals within and without the firm. Rajan and Zingales define access as "the ability to use, or work with, a critical resource” (p. 388). Examples of critical resources include machines, ideas, and people. As Rajan and Zingales make clear, "[t]he agent who is given privileged access to the resource gets no new residual rights of control. All she gets is the opportunity to specialize her human capital to the resource and make herself valuable.” (p. 388) Combined with her right to leave the firm, access gives the employee the ability to "create a critical resource that she controls: her specialized human capital." Control over this critical resource is a source of power. Rajan and Zingales argue that "[s]ince the amount of surplus that she gets from this power is often more contingent on her making the right specific investment than the surplus that comes from ownership, access can be a better mechanism to provide incentives than ownership.” (p. 388) Given the importance of access, the role of the firm is to allocate access efficiently amongst the firm’s agents. Again, employees play the most critical role.

Tellingly, perhaps, the theory of the firm which has had the most purchase on corporate law cares least about the role of employees within the firm. The "nexus of contracts" theory, originated by Jensen and Meckling (1976), argues that the firm is merely a central hub for a series of contractual relationships. Jensen and Meckling emphasize that the firm is a "legal fiction;" it is "not an individual" and has no real independent existence. The "nexus of contracts" theory has been extremely influential in shaping corporate law theory of the past three decades. (Easterbrook \& Fischel 1991; Ulen 1993; Bainbridge 2002). It has driven corporate law theorists to emphasize the non-mandatory nature of corporate law, both as a descriptive and a normative manner, and it has counseled against changes to the status quo based on the contractual nature (and arguable Pareto optimality) of that status quo (Ulen 1993).

Although Jensen and Meckling's model focuses on agency costs, it largely ignores employees as a whole. The agents in question are the upper-level managers who are tasked to do the bidding of principals. Their theory defines agency costs as the costs associated with monitoring by the principal, bonding expenditures by the agent, and the residual loss (Jensen \& Meckling 1976). The monitoring they describe does look a lot like the "control" that Coase focused on as the key element in defining the firm. ${ }^{21}$ However, Jensen and Meckling turn their attention to the relationship between shareholders (principals) and management (agents), rather than the relationship of employees to the firm. Their model seeks to describe the financial structure of the firm in conjunction with the management structure of corporate governance.

The nexus of contract theory is thus not really a theory of the firm at all, but rather a theory of agency costs within a certain type of firm (Hart 1989; Rock \& Wachter 2001, p. 1624). As McInerney has pointed out, "Scholars working in this paradigm do not offer theories of the firm so much as theories of who controls the firm.” (2004, pp. 137-38) Jensen and Meckling might argue that they make no bones otherwise, and that their project was primarily an analysis

\footnotetext{
${ }^{20}$ Blair (1999) refers to this as the "nexus of specific assets" model, based on an earlier version of the paper (p. $82 \&$ n.50).

${ }^{21}$ And indeed, Jensen and Meckling observe in a footnote: “As it is used in this paper the term monitoring includes more than just measuring or observing the behavior of the agent. It includes efforts on the part of the principal to 'control' the behavior of the agent through budget restrictions, compensation policies, operating rules etc.” (p. 308)
} 
on the positive aspect of agency costs theory in the corporate setting. But if we use the theory of the firm to determine the reasons why we have firms at all, the assumption of an investorcontrolled firm defeats the purpose of the exercise. Thus, the nexus of contracts paradigm isolates corporate law, as it "leaves corporate law focused entirely on financial transactions that are cut off from the primary strategic operating transactions of the corporation” (Rock \& Wachter 2001, p. 1629).

Economic theories of the firm have generally considered the employer-employee relationship to be critical, if not central, to the definition and purpose of the firm. This relationship is also critical to the definition of the firm in areas of the law beyond corporate law. The following section explores some of these areas.

\section{The Importance of Employees to the Firm in Other Areas of the Law}

Although this essay is a contribution to a volume on corporate law, I ask the reader's indulgence as we take a brief exploration into the role of the firm in other areas of the law. The purpose of this diversion is to show that unlike corporate law, other areas of the law regard the firm-employee relationship as central in defining the boundaries of the firm.

\subsection{Agency Law and Respondeat Superior}

As discussed above, the law of master-servant was for Coase the defining legal element of the firm. Since servants/employees were under the "control" of the master/employer, they followed the theory's predictions about what transactions would be within the firm (employment) and what transactions would be outside the firm (all others). This aspect of agency law has remained remarkably durable. The common law test for the employment relationship remains the control test. ${ }^{22}$

The control test states that when determining whether a person hired for labor is an employee, the primary factor is the hiring party's "right to control the manner and means by which the product is accomplished." 23 However, other factors are also taken into account, including "the skill required; the source of the instrumentalities and tools; the location of the work; the duration of the relationship between the parties; whether the hiring party has the right to assign additional projects to the hired party; [and] the extent of the hired party's discretion over when and how long to work." ${ }^{24}$ These factors also relate to the degree of independence of the worker from the firm.

\footnotetext{
${ }^{22}$ Clackamas Gastroenterology Assocs. v. Wells, 538 U.S. 440 (2003); Nationwide Mutual Insurance Co. v. Darden, 503 U.S. 318 (1992). The Restatement Third of Employment Law has modified this by describing employees as those who work in the interests of the employer when "the employer's relationship with the individual effectively prevents the individual from rendering the services as part of an independent business." (Restatement Third of Employment Law (2009), § 1.01(1)). Those who work outside of the relationship are distinguished because they exercise "entrepreneurial control over the manner and means by which the services are performed" (§ 1.01(2)). ${ }^{23}$ Darden, 503 U.S. at 323.

${ }^{24} \mathrm{Id}$. The court also includes "the method of payment; the hired party's role in hiring and paying assistants; whether the work is part of the regular business of the hiring party; whether the hiring party is in business; the provision of employee benefits; and the tax treatment of the hired party.” Id. at 323-24.
} 
Employees are also agents of the employer, and they fit within the general agency relationship (Restatement Third of Agency 2006, § 1.01). An agent can operate on behalf of the principal and can bind the principal by his or her actions (§ 2.01). An agent can act for the principal even when authority has not been expressly granted, as long as a third party reasonably believes the agent has the authority ( $\S 2.03$ ). Agency relationships can operate outside of the firm, and thus seem to contradict the notion that control is central in differentiating the firm from the market.

However, the distinction between employees and mere agents remains critical for the doctrine of respondeat superior. Under that doctrine, employers are liable for the torts committed by their employees within the scope of employment (Restatement Third of Agency $\S$ 2.04). This doctrine does not extend to principals' liability for the actions of agents. The reason is that the principal does not have the level of control over an agent that the employer has over its employees. As the Restatement describes: "Agents who are retained as the need arises and who are not otherwise employees of their principal normally operate their own business enterprises and are not, except in limited respects, integrated into the principal's enterprise so that a task may be completed or a specified objective accomplished. Therefore, respondeat superior does not apply.” (§ 2.04 cmt. b).

When it comes to tort, in a very real sense employees mark the outer boundaries of the firm. The firm is responsible for the actions of its employees but not for the acts of its mere agents. A corporation is not liable for the torts of its creditors, its customers, or its shareholders - only its employees. Interestingly, the doctrine of respondeat superior has generally been justified on risk-allocative or retributivist theories (Keeton et al. 1984, § 69). The employer may be seen as the best risk party to absorb the risk, either to deter the employee from harmful activity or to bear the costs of the injuries caused by the tort (Posner 2007; Baty 1916). The doctrine has apparently never been justified based on a theory of the firm. However, under a theory of the firm that seeks to explain joint production, the employee's effort on the part of the employer makes the conduct in question fall under the umbrella of the firm. The firm's scope is defined by its employees.

\subsection{Intellectual Property Law}

The relationship between employees and intellectual property is a fairly complex one. The term "intellectual property" refers to a wide range of information to which specific legal rights have attached. In some cases, intellectual property is generated by a single individual: an author writing alone in her home, or an inventor toiling away in the garage. However, in many cases, intellectual property is generated by specific individuals who are working within the context of a larger firm. How the rights to that "property" are divvied up have significant legal and economic ramifications, particularly for firms and individual employees (Stone 2004).

The role of the employee within intellectual property law is perhaps most evident in the work-for-hire doctrine. Under this statutory default rule, the employer is considered the author 
of any copyrighted work created by employees. ${ }^{25}$ The common law control test is used to determine whether the work was made by an employee or an independent contractor, and like respondeat superior, work-for-hire applies only to work produced within the scope of employment. $^{26}$ Thus, for purposes of copyright, the employee once again marks the boundaries of the firm; works made by employees within the scope of their employment are considered property of the firm, while works made by independent contractors are not (by default). The default rule for patent law is that the employee who invents the patent is the author, not the employer. $^{27}$ However, the employer is free to contract with employees explicitly for the rights to all inventions created within the scope of employment. Even without an explicit contract, courts have found something akin to a work for hire doctrine when an employee is hired to work on a specific invention or problem (Fisk 2009). In addition, under the shop-right doctrine, employers enjoy a non-exclusive right to use the patent without having to compensate the employee. A shop right arises when the employee has created the invention on the job using the employer's materials (Fisk 2009). Once again, the firm provides the context: if the employee creates the invention at work while using the employer's tools, the employer has a right to use that invention without cost.

Recent scholarship has made significant forays in using the theory of the firm to explain intellectual property law (Bar-Gill \& Parchomovsky 2009; Burk 2004; Burk \& McDonnell, 2007a, 2007b, 2009; Heald 2005; Merges 1999; Miller 2007). These theories use both the transaction-costs model and the property-rights model in demonstrating the connections between intellectual property, employees, and the firm. Using the transaction-costs model, Merges (1999) points to the concern about opportunism and holdups to explain why employers generally hold intellectual property rights over employee inventions. Heald (2005) focuses on transaction costs in explaining the patent system. Comparing a system of registered patents to a system based solely on trade secret protection, Heald argues that patent law makes it easier to buy and sell the information at issue. The patent buyer need not enter into a costly array of contractual protections in order to keep others (especially the sellers) from using the information. ${ }^{28}$ He also argues that patent facilitates the creation of technical information and the use of that information in team production. Patents enable the critical information to be used within the team without fear that one of the team members will defect. The alternative would again be costly contracts with all employees in the team. Without the need to monitor these contracts, the firm can facilitate team production more efficiently. ${ }^{29}$

The property-rights theory of the firm explicitly alludes to the importance of intellectual property. In describing the theory, Hart uses forms of intellectual property as examples of the "glue" that binds employees to the firm (Hart 1995). The protections for this type of property are

\footnotetext{
${ }^{25} 17$ U.S.C. § 201(b) ("In the case of a work made for hire, the employer or other person for whom the work was prepared is considered the author for purposes of this title, and, unless the parties have expressly agreed otherwise in a written instrument signed by them, owns all of the rights comprised in the copyright.")

${ }^{26}$ Community for Creative Non-Violence v. Reid, 490 U.S. 730 (1989).

${ }^{27}$ The patent must be registered by the individual inventor. See 35 U.S.C. § 111, 115 (discussing oath taken as part of patent process that the registrant is the "original and first inventor").

${ }^{28}$ Such contractual efforts would likely encounter difficulties, for example, if one of the seller's former employees sought to use the information.

${ }^{29}$ Heald (2005) also notes that some companies use patent applications, which must be filed by individuals, as a way of monitoring employee performance.
} 
designed to manage the interactions between firms as well as amongst the firm and its employees. For Burk \& McDonnell (2007a), intellectual property rights are a way to balance property interests between firms as well as within firms. Employees have an interest in exploiting information they have created on the job, both within the firm and outside the firm when on the job market. Patent, copyright, and trade secrets each balance the firm's needs and the individual employee's needs in separating employee information "assets" from firm assets. Burk and McDonnell point out that this division mirrors that of agency law and the corporate opportunity doctrine, in that the critical factors are whether the information/opportunity arose in the context of employment with the use of firm resources. Moreover, they point out that the weakest form of intellectual property protection - trade secrets protection - applies to the type of information most likely to overlap with an employee's own information capital (p. 609). This balancing of rights within firms and between firms leads to their "Goldilocks" hypothesis: the level of legal protection of intellectual property rights that minimizes transaction costs will be somewhere between a system that provides strong rights to firms and a system of weak rights for firms. ${ }^{30}$ And that balance includes the treatment of employee covenants not to compete, since their impact intersects with intellectual property, particularly trade secrets (Burk \& McDonnell 2007a; Bar-Gill \& Parchomovsky 2009).

Trademark presents a special connection between the firm, its employees, and intellectual property. Trademark protection is what enables a group of people to join together and be recognized as a common enterprise without fearing that their reputation will be poached by outsiders. Burk and McDonnell (2009) point out that just as patent, copyright, and trade secret protections concern the allocation of information rights between employee and firm, trademark concerns the allocation of good will and reputational rights between employee and firm. Trademarks enable firms to transfer reputational assets over to the firm, and thus deprive individual employees of their ability to hold up the firm over their own reputational assets (pp. 376-79). As in their discussion of informational property rights, Burk and McDonnell advocate for an intermediate approach, as depriving employees of any reputation rights would lead them to underinvest in reputation. They also discuss the critical role of trademark to franchise agreements. Allowing franchise entities to use the national firm's trademark permits a bifurcation between elements common to all users of the trademark (advertising, brand reputation) and elements handled individually by franchisees (hiring being the most prominent). Thus, franchising is an effort to restructure employment: it enables separate entities to break off into individual firms while maintaining the ability to share reputational assets with a national group. Franchisees need not be employees of the national firm in order to use the trademark.

In sum, these efforts to discuss intellectual property in terms of the theory of the firm demonstrate the importance of the firm to intellectual property law. And again, the boundaries of the "firm" are shaped by the relationship between the firm and its employees.

\subsection{Tax Law}

\footnotetext{
${ }^{30}$ Burk and McDonnell (2007a) argue that the level for interfirm transactions is calculated independently from the level for intrafirm transactions, although these levels could overlap or even be identical once calculated. Moreover, they indicate that employees are critical not only to intrafirm analysis, but also to interfirm analysis.
} 
Tax law has a well-known role in shaping choice of business organization, as certain organizational types such as partnerships and LLCs enjoy "pass through" taxation while most corporations are taxed as separate entities. Indeed, it was the changes in entity taxation that opened up the LLC revolution in the late 1980s and early 1990s (Ribstein 2010). However, when it comes to taxing based on the theory of a firm, the relationship between firm and employee also has an important role to play. Firms are expected to differentiate between employees and independent contractors over a host of provisions, including whether taxes need to be withheld, ${ }^{31}$ whether the firm must pay a share of Social Security and Medicare (FICA) and unemployment (FUTA) taxes for the worker, ${ }^{32}$ and whether the workers count as employees for benefit plan purposes. $^{33}$

The IRS defines employees based on the common law control test. ${ }^{34}$ The consequences of a misclassification can be extremely costly, as the business is then subject to the mandatory back-tax formula. ${ }^{35}$ In fact, Congress was moved to create a "safe harbor" for employers when it came to the employee-independent contractor distinction. ${ }^{36}$ The upshot of these requirements is to give the firm tax responsibilities for its employees, while giving independent contractors tax responsibilities for themselves. We thus see the differentiation between employee and independent contractor determining society's expectations about the firm's role in the worker's financial life. The firm is expected to manage and even pay some taxes for its employees, while it must leave independent contractors to their own devices. This responsibility accords with the broader picture of the myriad employment protections afforded under federal and state law only to employees. These employment-related protections - and the motivations behind them - are discussed more below in the final section.

\section{Reconsidering the Role of Employees in the Firm and Corporate Law}

\subsection{The Firm and Employment Law}

Employment law also does work in binding the employee to the firm. As Coase (1937) recognized in his seminal article, the common law control test for employees is the foundation for the firm. The control test defines an employee based on control and loyalty, and provides the legal apparatus for that structure (Masten 1991). All employees owe duties to the firm, including the duty of obedience, the duty of loyalty, and the duty to disclose relevant information to the employer. Masten likely overstates the importance of these doctrines to average employees, as they are unlikely to be enforced in that context. However, the duty of loyalty, when considered in context with covenants not to compete and trade secret protections, does bind the employee to the firm in meaningful ways. To the extent that the firm is meant to bind employees to a

\footnotetext{
3126 U.S.C. $\S 3402$.

32 26 U.S.C. $\S 3101$ et seq. (FICA); 26 U.S.C. $\S 3301$ et seq. (FUTA).

3326 U.S.C. $\S 410$.

34 Treas. Regs. § 31.3121(d)-1(c) (finding an employment relationship "when the person for whom services are performed has the right to control and direct the individual who performs the services, not only as to the result to be accomplished by the work but also as to the details and means by which that result is accomplished”).

3526 U.S.C. § 3509.

${ }^{36}$ Revenue Act of 1978, § 530.
} 
common enterprise, the common law duties required of employees reinforce this "glue" (Hart 1995).

The employment relationship is also defined by the "at-will” doctrine, which sets out the presumption that employees can be fired for any reason unless specified otherwise. This doctrine may seem unremarkable in this form, as it only creates a default rule, and the default is the general contractual default as well (Masten 1991). However, the at-will presumption is more than just a default rule; it is a presumption so strong that it sometimes can overrun contracting efforts that would normally be upheld. ${ }^{37}$ Other jurisdictions have looser forms of the presumption, and in some situations implicit terms or good faith protections will come to the aid of the employee. However, the presumption itself is a form of insulation to allow for greater managerial freedom. Rock and Wachter (2001) have argued that the at-will doctrine, like the business judgment rule in corporate law, is designed to create space for the operation of nonlegally enforceable rules and standards essential to firm governance. Regardless of those norms - which are arguably weakening - the at-will rule allows the legal space for the firm to easily separate itself from employees.

Employment law protections are perhaps then an attempt to provide certain benefits to employees based on their status within the firm. Employees do not control whether they can take time off for sickness or care of a newborn; employees cannot control whether they are subject to discrimination in promotions or whether they are paid overtime. We expect that those operating outside of a firm, however, do not have their time or activities controlled in such a manner that these remedies are necessary. The common law control test is used within many employment statutory schemes to differentiate between those who are entitled to the statute's protections and those who are not. ${ }^{38}$ Only employees can sue under Title VII for discrimination based on race, sex, or religion, ${ }^{39}$ or under the Age Discrimination in Employment Act for age discrimination, ${ }^{40}$ or under Title I of the Americans with Disabilities Act for discrimination based on disability. ${ }^{41}$ Only employees have their investment and retirement expectations protected under ERISA. ${ }^{42}$ Only employees have contractual minimums for wages and overtime. ${ }^{43}$ Only employees are

\footnotetext{
${ }^{37}$ For example, in New York oral evidence is not sufficient to overcome the presumption; the employment term must be established through specific written terms and there must be reliance on those terms. Wanamaker v. Columbian Rope Co., 907 F.Supp. 522, 539 (N.D.N.Y. 1995).

38 The Supreme Court assumes that Congress meant to use the common law test if the statute provides an unhelpful and/or tautological definition of employee. See Nationwide Mutual Insurance v. Darden 503 U.S. 318, 322-24 (1992). An example of such a statutory definition is "The term 'employee' means an individual employed by an employer." Title VII.

3942 U.S.C. $§ 2000 \mathrm{e}(\mathrm{f})$. In contrast, contractual exchanges are protected much more generally under 42 U.S.C. § 1981(a) ("All persons within the jurisdiction of the United States shall have the same right in every State and Territory to make and enforce contracts ....”).

40 29 U.S.C. § 630(f).

414 U.S.C. $\S 12111(4)$.

42 U.S.C. § 1002(6); Darden, 503 U.S. at 328.

${ }^{43}$ Fair Labor Standards Act (FLSA), 29 U.S.C. § 203(g). The FLSA defines employ as "to suffer or permit to work.” Courts have interpreted this definition more expansively under the “economic realities” test. Sec'y of Labor v. Lauritzen, 835 F.2d 1529, 1535 (7th Cir. 1989). However, the economic realities test largely overlaps with the control test; in fact, "control” is the first factor in the economic realities test. Id. at 1535-36.
} 
allowed to take time off from their contractual responsibilities to care for a newborn, tend to sick relatives, or recuperate from an illness. ${ }^{44}$

In considering why employees are protected by these statutory schemes, one might be tempted to say, "Well, of course these laws protect only employees; they're employment laws." But that overlooks an interesting question: why do we distinguish employees from other contractual partners when it comes to these laws? The answer is primarily that employees because of the employer's control over their labor - lack the market and legal power to meet their needs contractually. This disempowerment has been particularly acute in the corporation. Corporate law has definitively separated employees from the governance of the firm. As such, the corporation can control the fruits of individual employees' labor without interference from the laborers themselves. In order to balance out the employment relationship, the power that the firm has taken unto itself to better coordinate joint production must be mitigated through specific substantive protections that apply only to employees. ${ }^{45}$

\subsection{The Separation of Employees from the Corporation}

Firms need not have the effect of disempowering those who work for them or within them. The purpose of the firm is to overcome the effects of market-induced transaction costs and to faciltate team production around a core of common property. These purposes, in and of themselves, do not dictate that employees will be "servants" of the firm. In fact, the firm could be used as a device of employee empowerment. It allows a group of participants - workers and investors - to cumulate their resources under a common banner. Rather than competing against each other in a market or seeing their joint efforts held up by the opportunism of one person, employees could work together under a firm's collectivizing umbrella to produce as a team.

Intellectual property law provides a nice example of the employee-affirming possibilities of the firm. As described by Burk and McDonnell (2007a, 2009), intellectual property protections for information and reputation are designed (at least in part) to avoid holdups by individual employees. Patent, copyright, and trade secret law divvy up control and ownership of information assets between the firm and individual employees, and trademark divvies up reputational rights. Strong firm intellectual property protections are anti-employee only if the firm is separate from employees. If the firm represents the employees collectively, then assigning rights to the firm makes the employees as a whole better off. If all employees had individual rights, one employee looking to act opportunistically could hurt the other employees who have been following the rules and working cooperatively. Assigning ownership to individual employees would produce an anti-commons that fostered holdups and a breakdown of coordinated production (Merges 1999). Team production needs a place to assign ownership outside the individual participants, and the firm serves that function.

\footnotetext{
${ }^{44}$ The Family and Medical Leave Act uses the FLSA's definition of employee, which as noted above, is broader than the control test. The Department of Labor's regulations concerning the FMLA state: "In general an employee, as distinguished from an independent contractor who is engaged in a business of his/her own, is one who "follows the usual path of an employee' and is dependent on the business which he/she serves.” 29 C.F.R § 825.105.

${ }^{45}$ Greenfield (2008) makes this point, by noting that when employees are subject to employer opportunism, "[t]hey may demand a higher wage; they may demand more explicit job security protections; they may moderate their effort; they may solicit their legislators to protect them in other ways." (p. 1064) Of course, whether each of these statutes properly recalibrates the balance is subject to debate. I merely cite to their intent to address the balance.
} 
Why then do so many scholars (Fisk 2009, Noble 1977) lament the transfer of intellectual property rights from employee to firm? The issue, I would argue, has less to do with the ideal intellectual property system, and more to do with the governance of firms. If employees participated more robustly in firm ownership and governance, firms would act as a repository of employee collective rights. Instead, firms - constructed primarily as corporations - act as a tool for prying assets away from employees and into the hands of managers and investors. The construction of the firm as a business organization, which has been managed largely through corporate law, has been entirely different than the construction of the firm when it comes to agency law, property law, intellectual property law, and tax. So if we look at the firm not as a legal tool to facilitate team production, or not as an abstract placeholder for collective rights, but rather as a corporation, we see that the law has been taking rights away from employees and giving them to the corporation. The corporation, in turn, is governed by directors who are elected entirely by shareholders and who are charged with governing in the shareholders' interests.

\section{in information:}

Burk and McDonnell explicitly recognize this tradeoff when it comes to property rights

In transactions that involve inchoate firm-specific assets embodied in employees' human capital, both firms and employees face a hold-up problem. We have seen why the law might best assign rights to firms in such circumstances. However, this leaves employees open to exploitation, so that the opposite assignment might be better. Even if assigning rights to the firm is best, it is possible that protection of employees then requires assigning more power to employees within firms than we observe. (Burk \& McDonnell 2007a, p. 634-645)

This concern applies in other areas as well. In trademark, employees assign over their individual reputation rights to the collectivizing brand. Property and corporate law assigns any collective property to the corporation. Employees enjoy no property rights in what they produce or in their positions within the firm. And yet employees owe duties to the firm of obedience and loyalty, and their mobility may be constrained by covenants not to compete and trade secret law.

It is true that some employee-oriented doctrines favor society over the firm. The doctrine of respondeat superior, for example, makes the firm liable for the actions of all of its employees when they act within the scope of employment. However, when the firm becomes instantiated as the corporation, there is an answer: limited liability. Although investors may lose all that they invested, they are liable for no more. Limited liability is the one doctrine that had differentiated the corporation from other business forms for many years, and it is a direct response to one of the legal weaknesses of the firm. Tax law is the one area where corporations have been treated more harshly than other business organizations. Perhaps that taxation - so beneficial from a revenue perspective - is what drove legislators to give corporations such advantages in other realms of the law (Ribstein 2010). ${ }^{46}$

\footnotetext{
${ }^{46}$ This is a blunter version of a more complicated public choice argument that both corporate managers and Congress made peace over double taxation as it gave corporations an incentive to retain their earnings within the firm (Arlen \& Weiss 1995; Bank 2006).
} 
Under our current system, employees hand over assets to the firm, but then the firm established as a corporation - directs those assets to the shareholders. This dynamic provides the answer to those who insist that progressives should leave corporate law alone and instead focus on changes in labor and employment law (Smith 2008). A properly constructed corporation might not need layers of employment protections. A corporation can be described as "an association of stockholders formed for their private gain” (Dodd 1932, pp. 1146-47) only because the law established the corporation in that manner. The point of this essay is that the firm is naturally made up of employees, and it is corporate law that has divorced the employees from the firm.

\subsection{Moving from Firms to Markets?}

For those interested in reinvigorating an employee-centric view of the corporation, there is a further complication: both the corporation and the employment relationship seem to be declining in importance. The corporation is under siege by a plethora of new organizational structures, most notably the limited liability company (LLC). When the Treasury moved to "check-the-box" taxation for these new entities, they became viable alternatives to the corporation in a variety of different fields (Ribstein 2010). The flexibility of the LLC form is in

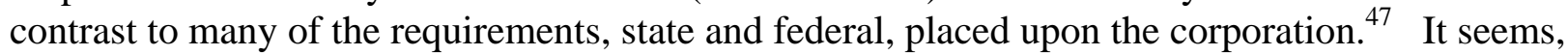
perhaps, as if Jensen \& Meckling's "nexus of contracts" model is coming to life in the LLC, and the corporation's failure to live up to the model is bringing it down.

The employment relation is moving from firm to market as well. In the mid-twentieth century, labor economists identified internal labor markets as a deviation from neoclassical labor market theory (Stone 2004). These economists found that employees largely stayed within one firm for their lifetime of employment, and that firms generally used internal promotion to fill vacancies. These findings established an empirical basis for Coase's notion of the importance of the employment relation to the firm. Moreover, internal labor markets are an instantiation of the separateness of the firm from the market; they demonstrate that the firm is truly a different set of relationships.

However, economists are finding that the importance of internal labor markets has been dwindling. Beginning in the 1970s, firms began to hire more temporary and contingent workers (Stone 2004). This trend accelerated through the 1990s, and continues apace. Recent reports indicate that the 2008 recession has turned many employees into "permanent" temporary workers, with as much as 26 percent of the workforce now having "nonstandard” jobs (Coy, Conlin \& Herbst 2010). And the effects go beyond low-skill and low-wage employment; executive officers, lawyers, and scientists are all among the temporarily employed (Coy, Conlin \& Herbst 2010; Greenhouse 2008). Moreover, “outsourcing” - a word of relatively recent vintage - continues to break down relationships that were traditionally within the firm (Geis 2009; Geis 2010; Blair \& O’Hara 2009). What Alan Hyde said in 1998 continues to be true

\footnotetext{
${ }^{47}$ Moreover, when it comes to the public corporation, commentators have suggested that more firms are going private because of the regulatory requirements layered upon the public corporation (Carney 2006). Bartlett (2009) argues, however, that Sarbanes-Oxley is not to blame for the high-profile "going private" transactions of the last decade.
} 
today: "Increasingly, labor is hired through short-term, market-mediated arrangements that may not be 'employment' relations in any legal or technical sense of that word.” (Hyde 1998, p. 99)

If the corporation is giving way to a more contractually-oriented form of business enterprise, and the employment relationship is dissolving back into the market, then perhaps corporations (or their successor organizational forms) will exist only to structure financial relationships and confer limited liability. There is reason to believe, however, that the firm and the corporation will remain relevant to our economic system. As even Ribstein (2010) acknowledges, the role of the "uncorporation" remains limited under current law. It seems likely that not only will the public corporation survive, but it will be made even less contractual after the passage of finance reform legislation. ${ }^{48}$ And in the employment context, the flight from employment seems driven by an effort to avoid employment-related regulations and restrictions, rather than the disappearance of the firm itself. In fact, many employers are looking to tie their employees even more closely to the firm and its image. The importance of "brand" for businesses means that employees are critical to reifying and promoting the brand, especially in service industries. Firms have used branding to draw out psychological commitments from employees that are not reciprocal on the part of the employer. Scholars have criticized this branding as too invasive, as it dictates what employees wear, what they say, and what they do when not on the job (Avery \& Crain 2007; Crain 2010). Control over employees in these industries is becoming more important to the role of the firm, not less.

In fact, it may be that the tide is turning back to a more employee-oriented workplace. Popular management literature emphasizes the importance of the employee (Bodie 2007). Companies like Costco and Patagonia are winning praise and success with an employee-focused orientation (Greenhouse 2008). Small startups, particularly in the tech industry, are once again blurring the line between entrepreneur and employee (Shafrir 2010). Academia is evolving, as well. As discussed earlier, recent research into the theory of the firm has focused on the importance of knowledge-based assets and the distribution of access top those assets within the firm (Rajan \& Zingales 1998; Gorga \& Halberstam 2007). In the corporate law literature, scholars such a Margaret Blair, Lynn Stout, Kent Greenfield, and Brett McDonnell are theoretizing a team-production and employee-centric approach to the corporation (Blair \& Stout 1999; Blair 1999; Greenfield 2007; McDonnell 2008). As we learn more about the importance of trust, norms, and procedural justice within the corporation, employees will grow even more in importance (Blair \& Stout 2001; Tyler \& Blader 2000).

It is possible to envision a radically individualized future, in which each worker is a “corporation” unto herself and firms are merely temporary agglomerations within the global market. It is also possible to envision a future in which employees participate at the highest levels of governance, and corporations are tools of team production rather than investor enrichment. Perhaps both of these futures are in store, to varying degrees within different industries. Further exploration into the role of the firm will make our choices in these regards more informed and thus more likely to be efficient.

\section{Conclusion}

\footnotetext{
48 The legislation paves the way for new regulations on compensation committees, say-on-pay proposals, and proxy access for director nominations. Dodd-Frank Act, Pub. L. 111-203, §§ 951-52, 971.
} 
Inquiries into the relationship between employer and employee are what drive the theory of the firm. Yet corporate law and corporate law theory spend little attention on this relationship. This essay is not meant as an argument for employee ownership, or even to advocate for specific forms of employee empowerment. ${ }^{49}$ Rather, it is to remind theoreticians of the importance of employees to the firm, and to recenter our studies of the firm around this relationship. Corporate law is where this neglect has been felt most keenly. Like the curious incident of the dog that didn't bark (McDonnell 2000), the puzzle of employees - silent within corporate law - has resisted a solution. Here's to hoping that bark is heard soon.

${ }^{49}$ For a fuller treatment of the pros and cons of employee ownership, see Hansmann (1996). His concern about worker heterogeneity, however, overstated the dire consequences of employee governance (Hayden \& Bodie 2009). 


\section{Bibliography}

Alchian, Armen A. \& Harold Demsetz (1972), "Production, Information Costs, and Economic Organization,” American Economic Review, 62, 777-95.

Arlen, Jennifer \& Deborah M. Weiss (1995), “A Political Theory of Corporate Taxation,” Yale Law Journal, 105, 325-90.

Asher, Cheryl C., James M. Mahoney \& Joseph T. Mahoney (2005), “Towards a Property Rights Foundation for a Stakeholder Theory of the Firm," Journal of Management and Governance 9, 5-32.

Avery, Dianne \& Marion Crain (2007), "Branded: Corporate Image, Sexual Stereotyping, and the New Face of Capitalism,” Duke Journal of Gender Law \& Policy, 14, 13-123.

Bainbridge, Stephen (2002), “The Board of Directors as Nexus of Contracts,” Iowa Law Review, 88, 1-34.

Bainbridge, Stephen (2003), "Director Primacy: The Means and Ends of Corporate Governance," Northwestern University Law Review, 97, 547-606.

Baldwin, Carliss (2007), "Where Do Transactions Come From? Modularity, Transactions, and the Boundaries of Firms," Industrial and Corporate Change, 1-41.

Bank, Steven A. (2006), "A Capital Lock-In Theory of the Corporate Income Tax", Georgetown Law Journal, 94, 889-947.

Bar-Gill, Oren \& Gideon Parchomovsky (2009), "Law and the Boundaries of TechnologyIntensive Firms,” University of Pennsylvania Law Review, 157, 1649-89.

Bartlett, Robert P., III (2009), "Going Private But Staying Public: Reexamining the Effect of Sarbanes-Oxley on Firms' Going-Private Decisions,” University of Chicago Law Review, 76, 744.

Baty, Thomas (1916), Vicarious Liability, Oxford, U.K.: Oxford University Press.

Blair, Margaret M. (1995), Ownership and Control: Rethinking Corporate Governance for the Twenty-First Century, Washington, D.C.: The Brookings Institution.

Blair, Margaret M. (1999), "Firm-Specific Human Capital and Theories of the Firm,” in Employees and Corporate Governance (Margaret M. Blair \& Mark J. Roe eds.), Washington, D.C.: The Brookings Institution, 58-90.

Blair, Margaret M. (2001), "Director Accountability and the Mediating Role of the Corporate Board,” Washington University Law Quarterly, 79, 403-47. 
Blair, Margaret M. (2005), "Closing the Theory Gap: How the Economic Theory of Property Rights Can Help Bring 'Stakeholders' Back Into Theories of the Firm,” Journal of Management and Governance, 9, 33-39.

Blair, Margaret M. \& Erin O’Hara (2009) “Outsourcing, Modularity and the Theory of the Firm,” Working Paper No. 09-19, Vanderbilt University Law School, Law \& Economics Series, available at: http://ssrn.com/abstract=1318263, 1-41.

Blair, Margaret M. \& Lynn A. Stout (1999), “A Team Production Theory of Corporate Law,” Virginia Law Review, 85, 247-328.

Blair, Margaret M. \& Lynn A. Stout (2001), “Trust, Trustworthiness, and the Behavioral Foundations of Corporate Law,” University of Pennsylvania Law Review, 149:6, 1735-1810.

Bodie, Matthew T. (2003), “Aligning Incentives with Equity: Employee Stock Options and Rule 10b-5,” Iowa Law Review, 88:3, 539-600.

Bodie, Matthew T. (2007), "Workers, Information, and Corporate Combinations: The Case for Nonbinding Employee Referenda in Transformative Transactions," Washington University Law Review, 85:4, 871-929.

Burk, Dan L. (2004), “Intellectual Property and the Firm,” University of Chicago Law Review, 71, 3-20.

Burk, Dan L. \& Brett H. McDonnell (2007a), “The Goldilocks Hypothesis: Balancing Intellectual Property Rights at the Boundary of the Firm,” University of Illinois Law Review, 2007, 575-636.

Burk, Dan L. \& Brett H. McDonnell (2007b), “Patent, Tax Shelters, and the Firm,” Virginia Tax Review, 26, 981-1004.

Burk, Dan L. \& Brett H. McDonnell (2009), "Trademarks and the Boundaries of the Firm,” William \& Mary Law Review, 51, 345-94.

Carney, William J. (2006), "The Costs of Being Public after Sarbanes-Oxley: The Irony of 'Going Private,"' Emory Law Journal, 55, pp. 141-60.

Clark, Robert Charles (1986), Corporate Law, Boston: Little, Brown and Co.

Coase, Ronald (1937), “The Nature of the Firm.” Economica 4 (4): 386-405.

Coy, Peter, Michelle Conlin \& Moira Herbst (2010), “The Disposable Worker,” Bloomberg BusinessWeek, Jan. 28, 2010, pp. 33-39.

Crain, Marion (2010), “Managing Identity: Buying Into the Brand at Work,” Iowa Law Review, 95, 1179-1258. 
Demsetz, Harold (2002), “Toward a Theory of Property Rights II: The Competition Between Private and Collective Ownership,” Journal of Legal Studies, 31:S2, S653-S672.

Dibadj, Reza (2005), “Reconceiving the Firm,” Cardozo Law Review, 26:4, 1459-1534.

Dodd, E. Merrick , Jr. (1932), “For Whom Are the Corporate Managers Trustees?”, Harvard Law Review, 45, 1145-63.

Easterbrook, Frank \& Daniel Fischel (1989), “The Corporate Contract,” Columbia Law Review, 89, 1416-48.

Easterbrook, Frank \& Daniel Fischel (1991), The Economic Structure of Corporate Law, Cambridge, Mass.: Harvard University Press.

Fisk, Catherine L. (2009), Working Knowledge: Employee Innovation and the Rise of Corporate Intellectual Property, 1800-1930, Chapel Hill, North Carolina: The University of North Carolina Press.

Foss, Nicolai, \& Peter Klein (2005), “The Emergence of the Modern Theory of the Firm,” working paper to be in THE THEORY OF THE FIRM: DEVELOPMENT, CHALLENGES, AND NEW DIRECTIONS, 1-57.

Geis, George S. (2009), “The Space Between Markets and Hierarchies,” Virginia Law Review, 95, 99-153.

Geis, George S. (2010), “An Empirical Examination of Business Outsourcing Transactions,” Virginia Law Review, 96:2, 241-300.

Gordon, Jeffrey N. (1997), “Employees, Pensions, and the New Economic Order,” Columbia Law Review, 97, 1519-66.

Gordon, Jeffrey N. (1999), "Employee Stock Ownership in Economic Transitions: The Case of United and the Airline Industry," in Employees and Corporate Governance (Margaret M. Blair \& Mark J. Roe eds.), Washington, D.C.: The Brookings Institution, 317-54.

Gorga, Érica \& Michael Halberstam (2007), “Knowledge Inputs, Legal Institutions and Firm Structure: Towards a Knowledge-Based Theory of the Firm” Northwestern University Law Review, 101:3, 1123-1206.

Grandori, Anna (2005), “Neither Stakeholder Nor Shareholder 'Theories’: How Property Right and Contract Theory Can Help in Getting Out of the Dilemma," Journal of Management and Governance, 9, 41-46.

Greenfield, Kent (1998), “The Place of Workers in Corporate Law,” Boston College Law Review, 39, 283-327. 
Greenfield, Kent (2007), The Failure of Corporate Law: Fundamental Flaws and Progressive Possibilities, Chicago, IL: University of Chicago Press.

Greenfield, Kent (2008), “Defending Stakeholder Governance,” Case Western Reserve Law Review, 58, 1043-65.

Greenhouse, Steven (2008), The Big Squeeze: Tough Times for the American Worker, New York, NY: Alfred A. Knopf.

Grossman, Sanford \& Oliver Hart (1986), “The Costs and Benefits of Ownership: A Theory of Vertical and Lateral Integration,” Journal of Political Economy, 94, 691-719.

Gulati, G. Mitu, William Klein \& Eric Zolt (2000), “Connected Contracts,” UCLA Law Review, 47, 887-948.

Gulati, G. Mitu, T.M. Thomas Isaac \& William A. Klein (2002), “When a Worker’s Cooperative Works: The Case of Kerala Dinesh Beedi,” UCLA Law Review, 49, 1417, 1453.

Hansmann, Henry (1996), The Ownership of Enterprise, Cambridge, Mass.: Belknap Press.

Hansmann, Henry (2006), “Corporation and Contract,” American Law \& Economics Review, 8, $1-19$.

Hart, Oliver (1989), “An Economist's Perspective on the Theory of the Firm,” Columbia Law Review, 89, 1757-74.

Hart, Oliver (1995), Firms, Contracts, and Financial Structure, Oxford: Clarendon Press.

Hart, Oliver \& John Moore (1988), “Incomplete Contracts and Renegotiation,” Econometrica, 56, 755-85.

Hart, Oliver \& John Moore (1990), “Property Rights and the Nature of the Firm,” Journal of Political Economy, 98, 1119-58.

Hayden, Grant \& Matthew Bodie (2009), “Arrow’s Theorem and the Exclusive Shareholder Franchise,” Vanderbilt Law Review, 62:4, 1217-43.

Heald, Paul J. (2005), “A Transaction Cost Theory of Patent Law,” Ohio State Law Journal, 66:3, 473-509.

Hirsch, James S. (1995), “Avis Employees Find Stock Ownership is a Mixed Blessing,” Wall Street Journal, May 2, 1995, B1.

Hyde, Alan (1998), "Employment Law After the Death of Employment," University of Pennsylvania Journal of Labor \& Employment Law, 1:1, 99-115. 
Jensen, Michael C. and William Meckling (1976), “Theory of the Firm: Managerial Behavior, Agency Costs and Capital Structure,” Journal of Financial Economics, 3, 305-80.

Keeton, W. Page, et al. (1984), Prosser and Keeton on Torts, West 5th ed.

Klausner, Michael (2006), “The Contractarian Theory of Corporate Law: A Generation Later,” Journal of Corporate Law, 31, 779-97.

McDonnell, Brett H. (2000), “The Curious Incident of the Workers in the Boardroom,” Hofstra Law Review, 29, 503-28.

McDonnell, Brett H. (2008), “Employee Primacy, or Economics Meets Civic Republicanism at Work,” Stanford Journal of Law, Business \& Finance, 13:2, 334-83.

McInerney, Thomas (2004), “Theory of the Firm and Corporate Governance,” Columbia Business Law Review, 135-96.

Macher, Jeffrey T. and Barak D. Richman (2008), “Transaction Cost Economics: An Assessment of Empirical Research in the Social Sciences,” Business and Politics, 10:1, 1-63.

Masten, Scott E. (1991), "A Legal Basis for the Firm," Journal of Law, Economics, and Organization, 4, Spring 1988, pp. 181-98, reprinted in The Nature of the Firm: Origins, Evolution, and Development, (Oliver E. Williamson and Sidney G. Winter, eds.), New York: Oxford University Press.

Means, Benjamin (2010) “A Contractual Approach to Shareholder Oppression Law,” Fordham Law Review, 79:3, 1161-1210.

Merges, Robert P. (1999), “The Law \& Economics of Employee Inventions,” Harvard Journal of Law \& Technology, 13, 1-54.

Meurer, Michael (2004), “Law, Economics, and the Theory of the Firm,” Buffalo Law Review, 52, 727-55.

Milgrom, Paul and John Roberts (1992), Economics, Organization and Management, Englewood Cliffs, NJ: Prentice Hall.

Miller, Joseph S. (2007), "Standard Setting, Patents, and Access Lock-In: RAND Licensing and the Theory of the Firm," Indiana Law Review, 40, 351-95.

Moll, Douglas K. (1999), "Shareholder Oppression v. Employment at Will in the Close Corporation: The Investment Model Solution,” University of Illinois Law Review, 1999, 517-81.

Noble, David F. (1977), America by Design: Science, Technology, and the Rise of Corporate Capitalism, New York: Alfred A. Knopf. 
Orts, Eric W. (1998a), "Shirking and Sharking: A Legal Theory of the Firm,” Yale Law \& Policy Review, 16, 265-329.

Orts, Eric W. (1998b), “The Future of Enterprise Organization,” Michigan Law Review, 96, 1947-74.

Osterloh, Margit \& Bruno S. Frey (2006), "Shareholders Should Welcome Knowledge Workers as Directors,” Journal of Management and Governance, 10, 325-45.

Pistor, Katharina (1999), “Codetermination: A Sociopolitical Model with Governance Externalities,” in Employees and Corporate Governance (Margaret M. Blair \& Mark J. Roe eds.), Washington, D.C.: The Brookings Institution, 163-93.

Posner, Richard A. (2007), Economic Analysis of Law, Aspen 7th ed.

Rajan, Raghuram G. \& Luigi Zingales (1998), “Power in a Theory of the Firm,” The Quarterly Journal of Economics, 113, 387.

Rajan, Raghuram G. \& Luigi Zingales (2001), “The Firm as a Dedicated Hierarchy: A Theory of the Origins and Growth of Firms,” The Quarterly Journal of Economics, 116:3, 805-51.

Restatement Third of Agency Law, Philadelphia, PA: American Law Institute.

Restatement Third of Employment Law, Philadelphia, PA: American Law Institute.

Ribstein, Larry E. (2010), The Rise of the Uncorporation, New York: Oxford University Press.

Rock, Edward B. \& Michael L. Wachter (2001), "Islands of Conscious Power: Law, Norms, and the Self-Governing Corporation,” University of Pennsylvania Law Review, 149, 1619-1700.

Roe, Mark J. (1999), “Codetermination and the German Securities Markets,” in Employees and Corporate Governance (Margaret M. Blair \& Mark J. Roe eds.), Washington, D.C.: The Brookings Institution, 194-205.

Shafrir, Doree (2010), “Tweet Tweet Boom Boom,” New York Magazine, April 26, 2010, pp. 34-41, 91-92.

Smith, D. Gordon (2008), “Response: The Dystopian Potential of Corporate Law,” Emory Law Journal, 57, 985-1010.

Smith, D. Gordon \& Cynthia A. Williams (2008), Business Organizations: Cases, Problems, and Case Studies, Austin: WoltersKluwer Law \& Business.

Stone, Katherine V.W. (2004), From Widgets to Digits: Employment Regulation for the Changing Workplace, Cambridge, U.K.: Cambridge University Press. 
Tyler, Tom R. \& Steven L. Blader (2000), Cooperation in Groups: Procedural Justice, Social Identity, and Behavioral Engagement, Philadelphia, PA: Psychology Press.

Ulen, Thomas (1993), “The Coasean Firm in Law and Economics,” Journal of Corporate Law, 18, 301-31.

Williamson, Oliver E. (1985), The Economic Institutions of Capitalism: Firms, Markets, Relational Contracting, New York: The Free Press.

Williamson, Oliver E. (1996), The Mechanisms of Governance, New York: Oxford University Press. 